\title{
Contested water rights in post-apartheid South Africa: The struggle for water at catchment level
}

\author{
JS Kemerink ${ }^{1 *}, \mathrm{R}_{\text {Ahlers }}{ }^{1}$ and $\mathrm{P}$ van der Zaag ${ }^{1,2}$ \\ ${ }^{1}$ UNESCO-IHE Institute for Water Education, PO Box 3015, 2601 DA Delft, The Netherlands \\ ${ }^{2}$ Water Resources Section, Delft University of Technology, PO Box 5048, 2600 GA Delft, The Netherlands
}

\begin{abstract}
The National Water Act (1998) of South Africa provides strong tools to redress inequities inherited from the past. However, a decade after the introduction of the Act, access to water is still skewed along racial lines. This paper analyses the various ways in which the Water Act is contested, based on empirical data detailing the interactions between smallholder farmers and commercial farmers in a case-study catchment in KwaZulu-Natal Province.

The paper argues that the legacy of the apartheid era still dominates the current political and economical reality and shows how the redistribution of water resources is contested by the elite. The paper identifies several issues that prevent the smallholder farmers from claiming their rights, including the institutional arrangements in former homelands, the 'community approach' of Government and NGOs, the disconnect between land and water reform processes, and historically-entrenched forms of behaviour of the various actors. The paper concludes that the difficulties encountered in the water reform process are illustrative for what is happening in the society at large and raises the question as to what price is being paid to maintain the current status quo in the division of wealth?
\end{abstract}

Keywords: natural resources, water reform, water rights, smallholder farmers, legal pluralism, South Africa

\section{Introduction}

Water use and management practices are a result of ongoing processes of negotiation and bargaining between different water users. The forum in which the negotiations over water take place is often characterised by legal pluralism, in which different normative orders coexist and interact (Von Benda-Beckmann, 1997; Bentzon et al., 1998; Boelens et al., 2005). Not all normative orders have the same coercive means; nor do all enjoy the same degree of legitimacy (Von Benda-Beckmann, 1997; Spiertz, 2000; Von Benda-Beckmann, 2002). At any location and in any point in time existing repertoires of water law and actual water use are therefore expressions of social-political and economic power relationships between people. Hence, proposed changes in water laws through water reform processes will often entail shifts in the socio-economic relationships which will benefit certain groups in society over others. Reform processes will therefore most likely be contested by some groups in society while other groups struggle to achieve the reformation (Mollinga, 2008; Mosse, 2008; Swatuk, 2008).

The impact of these power dynamics in society on the implementation of the water reform process becomes apparent in South Africa. The country has been haunted for decades by racial segregation under the so-called apartheid regime. The National Water Act (1998) formulated during the transition to the post-apartheid era is widely recognised in policy circles as one of the most comprehensive water laws in the world (Merrey, 2008). The Act defines the state as the custodian of the nation's water resources and only water required to meet basic human needs and maintain environmental sustainability is guaranteed as a

\footnotetext{
* To whom all correspondence should be addressed.

용 + 31152152 371; fax: +31 (0)15212 2921; e-mail: j.kemerink@unesco-ihe.org

Received 25 March 2010; accepted in revised form 5 September 2011.
}

right (RSA, 1998a). This fundamentally moves away from the previous water acts which were largely based on riparian water rights. The new Water Act gives the state a strong tool to redress race and gender inequities inherited from the past (Van Koppen and Jha, 2005). However, the National Water Act is implemented and enforced in a society thick with historically-entrenched socio-economic and political inequities. Hence, a decade after the introduction of the National Water Act access to water is still highly stratified along racial lines (Bond, 2006; Merrey, 2008; Cullis and Van Koppen, 2009). Recognition and understanding of the challenges met in the reform process could shed light on the forces at play in the resistance to redistribute the water. These insights can potentially contribute to better comprehending the struggles in the society at large.

This paper contributes to the ongoing discussion on the implementation of the South African National Water Act by presenting empirical evidence and analysing how the Water Act's goal to redress inequity is implemented and contested. This is done by illustrating the challenges faced by smallholder farmers in their struggle to increase access to (productive) water sources and their interactions with the commercial farmers in the area. The catchment used as a case study for this paper is located in the Thukela River basin in the south-eastern part of South Africa. The actual name and location of the catchment will not be revealed due to ongoing political sensitivities between various actors in the case-study area. (References used in this paper that directly refer to the case-study area will be indicated with 'undisclosed reference'. For verification purposes the references can be requested from the authors.) The findings presented are based on in-depth semi-structured interviews with 20 smallholder and commercial farmers within the catchment, carried out between June and August 2008. The interviewed smallholder farmers were selected by a stratified random selection procedure to guarantee geographical spread, to create a balance of age and gender, and to include less-advantaged farmers (see Box 1). The findings of the interviews were cross-checked through focus group 
Box 1:

Description of sample

The 18 selected smallholder farmers for the in-depth interviews permanently reside in the catchment in contrast to other residents who regularly commute to urban areas for longer periods of time. They are members of households located in different parts of the community and include members of large extended families residing in the area as well as farmers with few relatives living in the catchment. They have different political affiliations, sources and levels of incomes and educational backgrounds. All respondents are involved in agricultural activities and most own cattle. Out of the 18 smallholder farmers interviewed, 8 were women, of which $50 \%$ were older than 50 years and $50 \%$ were born in the community. Of the interviewed men, $70 \%$ were older than 50 years and $70 \%$ were born in the community.

The commercial farmers interviewed own the farms located directly downstream of the smallholder farmer community, including the commercial farmer whose property is (partly) located within the catchment. They are both male, born in South Africa from British descendents and under 50 years old. The commercial farmers live with their families on the farm.

discussions, observations, comparison with existing literature and by consultation of informants such as local authorities and non-governmental organisations (NGOs) active in the region. This paper first describes the theoretical framework used to analyse 4 ways in which water laws can be contested. In the next section a detailed narrative of the catchment is provided as well as the historical and institutional context in which the case study is situated. Thereafter the interactions between the actors in the catchment and the way in which they exert their water rights are analysed based on the theoretical framework. In the concluding section the impact of the contested Water Act on the access to (productive) water is discussed and the authors reflect on the consequences of the current situation for the society at large.

\section{Theoretical framework: contested water rights}

The main theoretical framework adopted in this paper is the concept of legal pluralism, which refers to the coexistence of and interaction between various normative orders in a society that govern people's lives (Von Benda-Beckmann, 1997; Boelens et al., 2005). The normative orders originate from different sources, such as political ideologies, economic doctrines, religions and projects. Legal pluralism recognises the dynamic, hybrid and ambivalent forms of laws that result from interaction between these normative orders within society, and allows for a greater understanding of the actual social meaning of rights in a specific social context (Boelens et al., 2005).

Water sector reforms often aim at changing socio-economic relationships between water users and most likely the proposed new laws and rights will therefore be challenged by various actors in a society. Zwarteveen et al. (2005) propose 4 categories in which water laws and rights can be contested taking into account a plural legal perspective, namely:

- The access to and control over water resources

- The content and interpretation of water law determining the water distribution

- The participation in decision making on water management

- The discourses underlying the water law and implementation policies

This section outlines the 4 categories as interpreted by the authors. The first category refers to how physical access to, and control over, the finite water resource is negotiated and obtained in plural legal societies and on which basis. In negotiating access, water users actively utilise the various normative orders to legitimise their claims to water depending on which normative order serves their interests best, i.e. so-called forum shopping (Bentzon et al., 1998; Meinzen-Dick and Pradhan, 2005). However, not all normative orders have the same coercive means, nor do all enjoy the same degree of legitimacy (Von BendaBeckmann, 1997; Spiertz, 2000; Von Benda-Beckmann, 2002). Actors with vested socio-political and economic powers can exert their stronger leverage position to influence which normative orders will prevail in the negotiations over water. Often the leverage position is closely linked to property ownership, such as infrastructure and land, as rights may become concretised rights over time, for instance, when rights become fixed in permanent concrete structures such as weirs, dams and field layouts (Mosse, 2008). However, powerful actors do not operate in isolation and the actual access to water resources is therefore an ongoing struggle between actors reflecting these social-political and economic interdependencies.

The second category is related to the conflicts and disagreements on the content of norms and laws and how they (should) determine rules and regulations on access to water. This category refers to the interpretation of water laws and the social meaning of water rights in society. It reflects the socio-economic power relations between the various actors and does not simply follow technical imperatives such as efficiency, but also reflects the historical and cultural values and ideas upheld in society. How water rights are understood and translated to rules for water use is coloured by the locally-accepted ways and traditions of dealing with water (Zwarteveen et al., 2005; Mosse, 2008).

The third category deals with the struggles over participation in decision making over water law and rights. Decision making spaces are often exclusive in the sense that some people are allowed to enter and participate in them and others not. Exclusion may be direct, based on class, gender or ethnicity. However, often exclusion is less direct and hidden in membership criteria, location of the meetings or language used. Moreover, being included in participation processes does not guarantee one's voice is heard as participation in decision making is determined by social relationships of power and dependency (Cleaver, 1999; Cornwall, 2003). Cultural norms associate certain forms of behaviour with knowledge and authority and others with ignorance, and in this way prescribe certain forms of behaviour to different social groups of people (Bentzon et al., 1998; Zwarteveen et al., 2005). This directly influences the selfperceived capacity to participate in decision making and may even lead to self-exclusion (Wilson, 1999).

The last category in which water law and rights can be contested lies in the discourses used to articulate water problems and solutions. The way in which water problems and solutions are defined and conceptualised in a society is closely linked to the political agenda they promote (Molle, 2008; Mosse, 2008). Any understanding of water problems is based on representations and always implies a set of assumptions and (implicit) social and political choices. Knowledge produced on water is not merely neutral or scientific; it does not emerge by chance but, rather, is the emanation of complex webs of interests, ideologies and power as an inherent part of the water sector (Molle, 2008). Hence, the dynamics of water politics, including water law and rights, cannot be understood without also scrutinising the power relations, discourses and discursive practices that guide perceptions of water problems and proposed solutions. In an ever more globally-connected world order, this category includes analysing global political forces and global networks that influence 
the national policies on water (Conca, 2006; Mollinga, 2008; Swatuk, 2008).

\section{Historical and institutional context of the catchment}

The case-study catchment is located in the Thukela River basin, in the foothills of the Drakenberg Mountains, located within the KwaZulu-Natal Province. The upstream part of the catchment is part of a former Zulu homeland and is inhabited by smallholder farmers. At the downstream end of the catchment commercial farms are located. This section describes the historical and institutional context of the catchment as well as the physical and socio-economic conditions in the case-study area.

The Zulu tribe originates from Bantu communities and settled in the area in the $16^{\text {th }}$ century. A crucial turning point in Zulu history occurred during the reign of Shaka (1816-1828). Prior to his rule, the Zulus consisted of numerous clans that were related but disorganised. During Shaka's reign conquered tribes were incorporated into the Zulu kingdom (Omer-Cooper, 1994). In 1653 , the south-western part of South Africa was colonised by the Dutch and around 1825 the British settlers arrived on the east coast (Omer-Cooper, 1994; Wilson and Thompson, 1969). The Zulus fought several wars against the British, but surrendered in 1906. From then on the tribe was subjected, by European settlers and their descendents, to an increasingly harsh series of racist laws and practices that led to the disempowerment and subordination of the Zulus and other Black African tribes and which dispossessed them of access to natural resources (Mamdani, 1996).

Apartheid was a system of legalised racial segregation enforced by the White-dominated Government of South Africa between 1948 and 1994. Under apartheid, a series of measures were introduced as part of the policy of so-called 'separate development' that intended to create a South African society in which the White population would become the demographic majority. The creation of homelands was a central element of this strategy. Comprising no more than $14 \%$ of the country's area, 10 arbitrary and often highly fragmented administrative territories were created in 1951 (Pickles and Weiner, 1991). These homelands were supposedly the original areas of settlement of what the state had identified as the country's main African ethnic groups and the Black population were made citizens of these homelands, denying them South African citizenship and voting rights (Mamdani, 1996). Within the homelands the Black Africans could aspire to self-rule under a chieftaincy (Ross, 1999). This subjected the inhabitants to the chiefs and made them lose access to ancestral land. Local tribal leaders were appointed by the Government to run the homelands, and uncooperative chiefs were forcibly deposed. By incorporating the traditional governance structure and paying salaries and other benefits to the traditional chiefs, the apartheid regime kept influence over the semi-autonomous homelands and could control resistance (Mamdani, 1996). Over time, a ruling Black elite emerged with a personal and financial interest in the preservation of the homelands. On advice of the apartheid Government large-scale reorganisation of the land use in the homelands was introduced under the Betterment Schemes. The reorganisation included dividing the land into distinct land-use zones, e.g., residential, arable and grazing areas. People living in the homelands were forced to move into demarcated residential zones and dispossessed of arable and grazing land. Only small plots were given to households to ensure the most basic crop production. The expressed goal of the Betterment Schemes was to 'rehabilitate' the land from the perils of overgrazing and 'inefficient' African land use, but, in reality, the
Betterment Schemes facilitated increasing the population densities in the homelands (McCusker and Ramudzuli, 2007). The homelands became economically weak as the high population densities often far exceeded the carrying capacity of the land (Pickles and Weiner 1991; Ross, 1999). The education system was designed to prepare the Black population for manual labour and, with few local employment opportunities being available in the homelands, most men commuted to work on the commercial farms and in the mines of White South Africa (Bond, 2006). Women often stayed behind and were relegated to reproducing the future labour force and taking care of the sick and elderly (Penzhorn, 2005; Omer-Cooper, 1994). The apartheid politics sparked significant internal resistance. A series of uprisings and protests led to an armed resistance struggle against the White Government. Bloody armed clashes also occurred between opposing Black political parties, especially between the African National Congress (ANC) and the Zulu-dominated Inkatha Freedom Party (IFP). This violence, believed to be supported by the security forces of the apartheid Government, escalated at the end of apartheid. Today the tension between political parties still exists. Political apartheid was finally dismantled under internal and international pressure in a series of negotiations on the revision of the constitution from 1990 to 1993 (Omer-Cooper, 1994). The negotiation culminated in democratic general elections of 1994, which gave a landslide victory to the ANC.

Reconciliation of the society was the major concern of the new Government and it took on the transformation of the discriminatory legal systems. The Constitution was rewritten, as well as most laws, such as the National Water Act. As part of the institutional reform the Government structures were redefined and the homelands were dismantled, reincorporating their territory into the Republic. The national, provincial and local government levels all have legislative and executive authority in their own spheres and are defined in the South African Constitution as distinctive, interdependent and interrelated. The Constitution also acknowledges traditional governance structures and states that the country should be run on a system of cooperative governance (RSA, 1994). Prime advisory bodies of traditional leaders exist at all government levels and in the former homelands the traditional structures still play a formal executive role in addition to the local government structure (Lehman, 2007).

The case-study catchment (Fig. 1) occupies a total area of approx. $10 \mathrm{~km}^{2}$ of hilly terrain with generally acidic soil. The mean annual rainfall is estimated to be $700 \mathrm{~mm} / \mathrm{yr}$ and the estimated potential evaporation is between 1600 and $2000 \mathrm{~mm} / \mathrm{yr}$, at an elevation of about $1250 \mathrm{~m}$ above sea level. A good drainage network has developed in the catchment with most of the streams being perennial. Extreme low flows occur in winter time between June and August (undisclosed reference).

The former Zulu homeland located in the upstream part of the catchment is mainly inhabited by smallholder farmers. The population in this part of the catchment fluctuates considerably as many commute to urban areas; however, it is estimated that around 500 people reside in the area on a permanent basis. Herding cattle and practicing agriculture are the main activities in the area. Box 2 provides details on the water sources used by the smallholder farmers. Cattle are kept for cultural reasons, although for a few farmers they also serve for commercial purposes. The cattle graze in summer time on communal land in the upper part of the catchment. Overgrazing has led to extensive soil erosion which has negatively influenced the natural water retention in the catchment (undisclosed reference). The agricultural plots are relatively small ( 0.5 to 2 ha) and the main crops grown are maize and beans for subsistence, although parts of the 


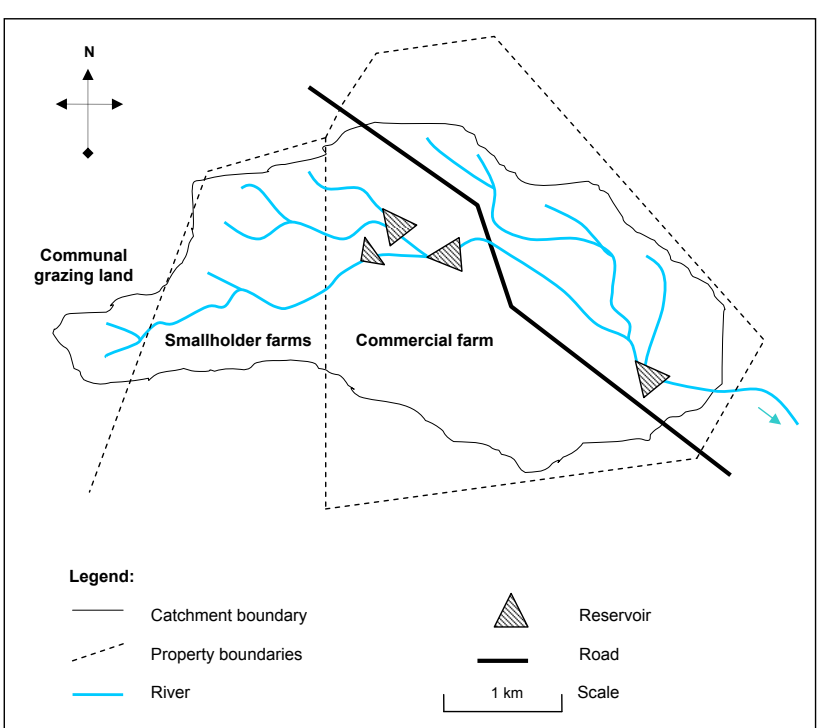

Figure 1

Sketch of the catchment

harvest are regularly sold. Supported by NGOs, an increasing number of smallholder farmers are growing vegetables in home gardens. The agricultural activities are not the main sources of income in the catchment as $37 \%$ of the households earn a regular income, $45 \%$ of the households have access to remittance from family members working elsewhere, and $82 \%$ of the households receive social grants from the Government (undisclosed reference), such as child support, old-age pension and disability grants (also available for HIV/Aids patients). The child support grant is ZAR 210 per child per month, while the latter two amount to ZAR 940 per month (SASSA, 2008). In addition, some smallholder farmers generate considerable income from illegally growing marijuana.

A commercial farm is located at the downstream end of the catchment with a total area of 1560 ha. The commercial farm was established about 100 years ago and has been owned by 3 different families, all of British descent. The current farmer has owned the farm since 2002 . The property includes 4 surface dams allowing the farmer to grow irrigated crops in both summer and winter seasons (see Fig. 2). The farmer has registered his historical water use under the new water law, which means his water use is recognised as an existing lawful use (RSA, 1998a).

Between the smallholder farmers and commercial farmer various direct links and interdependencies exist. The perennial streams in the former homeland replenish 3 of the 4 reservoirs of the commercial farmer downstream. However, the water carries considerable sediment loads caused by erosion in the upper part of the catchment. The sediments are trapped in the dams of the commercial farmer reducing their storage capacity. During the winter months the cattle of the smallholder farmers roam the fallow fields and often trespass into the commercial farm. The cattle damage the crops of the commercial farmer and regular conflicts arise on this matter. In addition, interdependencies are created by the employment relationship: the commercial farmer employs approx. 30 permanent workers and up to 150 temporary workers during the harvest season. Most workers on the commercial farm are residents of the case-study area while some others come from the surrounding areas.

The smallholder and commercial farmers residing in the catchment fall under the formal authority of the local municipality and are represented by an elected councillor at ward level in the municipal council. The composition of the municipal council is based on a mixed system of proportional representation and the constituency election system. The IFP is the ruling party in the municipality in which the catchment is located, while the $\mathrm{ANC}$ has the majority at provincial and national level. Amongst others, the municipality has the responsibility to ensure the provision of services (including water supply) to communities in a sustainable manner and to promote social and economic development (RSA, 1998b). In the former homeland, the traditional governance structure is still operational and the local chief controls access to land resources as custodian of the state-owned land. The land tenure reforms aiming at granting private ownership of land to the people living in the former homelands is highly contested by the traditional authorities (Lyne and Darroch, 2004). The traditional Zulu governance structure used to have committees of elderly men at village level and headmen at a
Box 2:

Water sources used by smallholder farmers in the catchment

The smallholder farmers mainly use communal boreholes for domestic purposes. The boreholes are freely used and even though few rules on water use exist, they are not adhered to. Not all boreholes work properly and some households are located more than $1 \mathrm{~km}$ from the boreholes. During the winter the farmers suffer from water shortages, sometimes even for domestic use when boreholes run dry. The cattle mainly drink from creeks and natural springs and some farmers have built small earthen dams on their plots to water their cattle. For agricultural activities the smallholder farmers primarily rely on rainfall. However, some home gardens are irrigated with water from the boreholes or springs. With support from NGOs, a few farmers have installed rainwater harvesting tanks, which collect runoff from the compounds and enable them to grow (supplementary) irrigated crops.

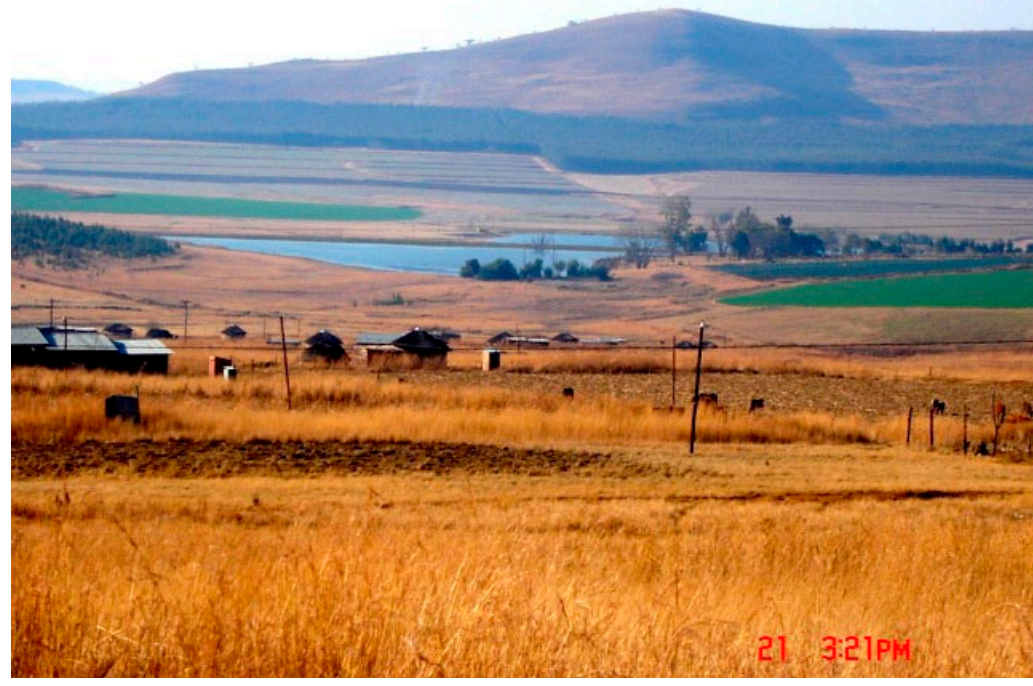

Figure 2

Photograph of the catchment, showing the houses and fields of the smallholder farmers in the forefront, and 2 reservoirs and irrigated lands of the commercial farm downstream (July, 2008) 
higher spatial level as intermediaries under the chief. However, to make the traditional governance structure more compatible with the local municipality structure, the committees at village level in the case-study catchment have been replaced in 2003 by elected leaders at ward level and elected councillors have been introduced in the council of the chief (RSA, 2003).

\section{Contested water rights in the catchment}

Although the National Water Act (1998a) directly aims at redressing the injustice of the past, inequities in access to water still exist in the catchment: so far the commercial farmer has kept his entitlements to the water and the water allocations to the smallholder farmers have not increased. This chapter presents the empirical data from the case-study catchment and analyses the interactions between the various actors and the way in which they exert their water rights, following the framework presented in second section of this paper.

\section{Category 1 - Access to and control over water}

The current South African society is characterised by multiple legal realities. During apartheid, 2 different formal legal systems coexisted, the legal system in the White Republic and the legal system in the homelands. The legal system in the Republic focused on limiting power of the state and guaranteeing rights to its citizens, while the legal system in the homelands focused on strengthening the influence of the authorities to enforce customs upon its residents (Mamdani, 1996). After apartheid this was replaced by a new legal system; however, in contemporary South Africa the 2 legal systems of the apartheid era continue to exert their influence. In addition, as in every society, various normative orders, such as political ideologies, cultures and religions, coexist and influence in complex ways the context in which the negotiations over access to water take place. The Water Act is contested by various actors in society which are interlinked through social relationships and interdependencies. In the contemporary capitalist South African society the coercive means of the vested economic powers are strong (Bond, 2006; Swatuk, 2008). Large-scale water users such as commercial farmers, mining industries and electricity companies continue to receive water on economic grounds (Steyl et al., 2000). Research conducted in the northern parts of South Africa shows that wealthier people are better able to capture the available resources (Hope et al., 2004; cf. Mosse, 2008; cf. Sjaastad and Cousins, 2008). As a result, the highly stratified division of economic power along racial lines, and the status-quo of access to water resources in the study catchment is maintained.

The plural legal conditions in which access to resources has to be negotiated in former homelands is characterised by a more complex reality than in other parts of the country, as a result of the formal coexistence of the municipality and the traditional governance structure at local level. This coexistence determines that the municipality is responsible for water supply and the socio-economic development of the village (RSA, 1998b), while land tenure falls under the authority of the chief in study area. Close collaboration between the 2 institutions is required to ensure access to land with adequate opportunities to exploit water resources and sufficient tenure security to invest in hydraulic infrastructure. However, according to the interviewed farmers, in the case-study area the institutions compete to increase their authority within the catchment. Only 3 of the 18 interviewed smallholder farmers expressed trust in the local municipality whereas the other farmers regard it as being corrupt and dominated by struggles between the political parties. Almost all interviewed farmers are dissatisfied with the service delivery of the municipality. Ten interviewed smallholder farmers indicated that, as in the apartheid era, chiefs play an active role in politics. According to the smallholder farmers, chiefs are loyal to political parties in return for continuing support to legitimise their authority and other favours. In a young democracy with a large illiterate rural population voters can easily be manipulated and the chieftaincy fosters strongholds for the political parties. Four smallholder farmers indicated that the level of municipal service delivery to their community is low because the ruling chief belongs to the opposition party (ANC). They argue that, therefore, most smallholder farmers in the former homeland voted for the same opposition party; however, the elected councillor of the ward is from the ruling party (IFP).

The authority of the chief has lost legitimacy among the rural population as chiefs were seen as puppets of the White Government during apartheid (Mamdani, 1996). However, the current party politics and the state-introduced changes in traditional governance structure have also reduced the executive power of the traditional authority in the case-study area. According to 8 interviewed farmers, as a result of the imposed changes (e.g. the abandoning of the committee of elders) no institution has sufficient authority to spearhead joint initiatives at village level. For example, plans for jointly building small reservoirs for watering livestock and for irrigation have not materialised because of disputes over the location of the dams. Although access to land is controlled by the chief, the traditional structure does not have sufficient authority to make land available to the benefit of the community as a whole, and unused land is hardly available in the area as population density is high. The local politics leave the smallholder farmers in the catchment divided along party lines. The smallholder farmers indicated that village meetings are occasionally organised, but are mainly limited to conflict mitigation and providing top-down information, and are not used to discuss opportunities for progress or planning of joint initiatives. Although more than half of the smallholder farmers carry out joint activities, such as growing beans for sale and weaving mats, participation is limited to family members or political allies and these activities are often externally supported by NGOs.

Besides differences in political affiliations the composition of the community is also heterogeneous in terms of agricultural ambitions. Most smallholder farmers keep cattle for cultural purposes; however, only 6 farmers have the ambition to advance their crop-growing activities for commercial purposes. It should be noted that during apartheid considerable segments of the Black population had been de-urbanised during the forced relocation to the homelands (Mamdani, 1996). This could explain why agricultural ambition is relatively low in the former homeland. The heterogeneity of the community and associated difference in priorities gives the people who would like to farm a disadvantaged starting point in accessing municipal services which are often offered on a communal basis. It also negatively influences the negotiations over the redistribution of land and water with the downstream commercial farmer. Without a clear mandate to negotiate on behalf of the community the villagers are faced by a far more powerful opponent in the commercial farmers. The commercial farmer located at the downstream part of the catchment indicated that several smallholder farmers contacted him to discuss redistribution of natural resources: they requested access to part of his (fallow) land, receiving wood and support with constructing a dam upstream of his reservoirs. Instead, the commercial farmer has interest to jointly develop 
new water resources. However, according to him there is no established authority among the smallholder farmers with whom to thoroughly discuss the issue, and, in his opinion, the community is highly disorganised. In the absence of local government and/or the traditional authority to facilitate the negotiation process it leaves the smallholder farmers with virtually no opportunity to improve their access to the natural resources. Although, most likely, the legal plurality in the former homelands creates an enabling environment for certain groups to exert their claims, it also creates institutional chaos which prevents some smallholder farmers in the catchment from addressing the unequal access to natural resources and pursuing their agricultural ambitions.

\section{Category 2 - Content and interpretation of water rights}

The content of the National Water Act and how it should be interpreted is debated at various points. For example, the Act defines that water required to meet basic human needs is guaranteed as a right and all other water uses by humans are divided into priority categories (RSA, 1998a). The policy to implement this particular part of the Act identifies water for basic human needs only as water for domestic use and limits it to 25 litres per person per day. However, many smallholder farmers depend to a large extent on their own food production for their subsistence, and it can therefore be debated if and how water for subsistence farming should be included in the basic human needs (Hope et al., 2008). The guaranteed right of water used for environmental sustainability is also questioned (Swatuk, 2008) and is sometimes seen as a hobbyhorse of the White elite. Some smallholder farmers in the Olifants River Basin responded to water allocated to the environment with: 'As if they (read Whites) find fish more important than our lives' (Van Koppen and Jha, 2005: 209).

The Act also clearly indicates that the Government can reallocate water to redress the inequities in the society, but the reallocation is only legitimate if it is in the wider public interest (RSA, 1998a). However, it can be debated what the wider public interest is. Currently the Government recognises a need to 'balance' equity with productivity and profitability and is cautious about large-scale reallocations (Merrey, 2008). This approach is supported by the commercial farmer in the catchment, whose position is that he invests his own capital and takes financial risks to produce food to feed the rural population. He argues that if the land and water resources are given to the lessexperienced Black population, the agricultural production will significantly drop, which will negatively influence the national economy and is therefore not in the public interest. With the economic meltdown in neighbouring Zimbabwe, which, according to some politically-motivated voices is directly linked to the forced take-over of White-owned farms, most smallholder farmers in the catchment tend to agree with him; 14 interviewed smallholder farmers acknowledge the role of the commercial farmers in the national economy and stress the need for a good relationship with the commercial farmers, regardless of the division of natural resources (cf. Van der Zaag and Röling, 1996). The domination of fear in the debate through the comparison with Zimbabwe is a powerful tool in the hands of the commercial farmers to influence the societal meaning of 'the wider public interest', and in this way to maintain the status quo. However, 3 interviewed smallholder farmers explicitly indicated that a more fair distribution of natural resources is a prerequisite to improve the relationship with the commercial farmer downstream in the catchment. In addition, according to several smallholder farmers, the youth might not accept the current distribution of resources and threats to the commercial farmers are reported. An elderly female smallholder farmer ( 71 years) indicated that, in the absence of intimidating memories of the apartheid era and openly supported by some political movements, "the youth might challenge the uneven relationship with the commercial farmers in the near future and might call for the Zimbabwean approach'.

\section{Category 3 - Participation in decision making}

The new legal system in South Africa makes a major shift in participation in decision-making processes in comparison to the apartheid era in which Black South Africans were excluded. Even though the formulation of the Water Act incorporated public views, and public participation during the implementation phase is stipulated, the decision-making spaces are still dominated by Whites and some Black elites (De Lange, 2004). Technical expertise and knowledge of water resource management is still White-dominated and the Government agencies have suffered greatly from 'brain drain' to private consultants as a result of the Black Economic Empowerment Act which focuses on achieving equity in (Government) employment (RSA, 2004). Nowadays the Government is highly dependent on hiring consultants to implement the Water Act and to facilitate public participation, while these consultants do not necessarily serve the interests of the Government nor are they necessarily familiar with the needs and desires of the Black community (Merrey, 2008). With 11 official languages in South Africa, language also plays a role in public participation, as most meeting are held in English and only partly translated in other languages (Van Koppen and Jha, 2005). High illiteracy rates in rural South Africa seriously hamper the involvement of rural communities (Simpungwe, 2006).

For public participation to be effective in decision making, liaison with interest groups is essential. Within the participation process the rural communities are often categorised as one single interest group, for instance, for their representation in the water user associations that will be established under the Water Act (authors' unpublished data). The smallholder farmers in the catchment are faced with the challenge that they are often expected to act on a communal basis in participation processes while they are strongly divided amongst themselves. Underlying causes of the difficulties for the community to act collectively are the weak family ties as a result of the resettlement policies and the condemnation of every form of self-organisation during apartheid. Moreover, the perception of dependency on external support (e.g. Government and NGOs) for development is strong, as 14 smallholder farmers indicated that external institutions have to take care of their (basic) needs. The (limited) monetary resources available in the community are barely invested in productive activities and confidence in their own entrepreneurial skills is low. When asked what they do for a living more than half of the smallholder farmers indicated that they do not have an occupation (any longer) and rely on social grants from the Government. Only 4 out of 18 smallholder farmers acknowledge their own agricultural activities, even among the smallholder farmers who regularly sell their surplus. Potentially the dependency created during apartheid undermines the self-reliance of the smallholder farmers and limits their self-esteem to participate in decision making on water resources.

The scars from the past still dominate the relationship with the downstream commercial farmer. Although various interdependencies exist between the smallholder farmers and the commercial farmer and both parties would benefit from a good 
relationship, the smallholder farmers feel inferior and believe they depend more on him than the other way around. Although the commercial farmer realises that he is the minority in the area and his farm could be occupied overnight, he also believes the smallholder farmers will not take the risk to illegally challenge the current situation as he employs a considerable number of community members on his farm. For water, the commercial farmer is dependent on the smallholder farmers as most of the water in his reservoirs originate from their area; nevertheless he indicated that his current water entitlement gives him sufficient confidence that he will continue to receive water in the future. For reallocation of water under the Water Act downstream lawful uses have to be considered and compensated if negatively affected, unless it can be proven that the reallocation is to 'rectify an unfair or disproportionate water use' (RSA, 1998a: 22-7). Nevertheless the commercial farmer trusts that he has a strong case to oppose potential redistribution of water in the catchment, which worries the smallholder farmers who are less familiar with the content of the Water Act. The understanding of each other's realities and respect for cultural values is limited. The smallholder farmers indicated that they have invited the commercial farmer, in vain, to several official ceremonies in the community to strengthen the bond between them. The commercial farmer indicated that he does not have time to attend the time-consuming ceremonies and prefers to limit their interaction to purely business matters. The local government is absent in bringing the parties together to facilitate the reconciliation process and foster collaboration. Currently, communication between the parties is restricted to conflict mitigation over cattle trespassing. Five smallholder farmers indicated that, out of frustration over the current situation, people living in the case-study area sabotage the activities of the commercial farmer, e.g., deliberate trespassing of cattle on the commercial farm, stealing of crops, and destroying equipment. Although it affects his business, the commercial farmer indicated that he does not act on this impairment but tolerates it to avoid it becoming worse. Both parties pointed out that potential collaboration on the development of alternative water resources is seriously affected by the current negative relationship.

The Water Act is explicit in its aim to redress the inequities based on gender (RSA, 1998a) and mainly refers to providing domestic and productive water to poor women in the rural areas. However, some cultural values obstruct participation of women in decision making. The Zulu culture is patrilineal in which the customary heritage of property and power positions is through the male lineage, from father to son (Mair, 1969). In the Zulu culture women have limited political status, and resources such as land and livestock are mainly owned by men. Although water resources are mainly used by women for domestic purposes, and growing crops is regarded a female activity, women are not involved in the maintenance and future planning of the water resources and have a low political status (Penzhorn, 2005). Three female smallholder farmers indicated that they would like to be involved in decision making at village level, but, for community meetings, often only men are invited. The few women who do attend the meetings on their own initiative indicated that they have difficulties in speaking up and being heard. In particular the presence of male relatives of their husbands restricts them from raising their voices. Half of the interviewed women in the catchment are not aware of the institutional structures in their community and indicated that men do not inform them about governance issues. Two male farmers responded that the village meetings focus primarily on issues related to cattle which they regard as a male business. Joint initiatives of women to increase their influence in the community do not take place, according to the interviewed female farmers, because the women in the community are not united. Some NGO-supported agricultural groups include women (undisclosed reference); nevertheless, the decision-making spaces remain strongly male-dominated.

\section{Category 4 - Discourses underlying water law and implementation policies}

The National Water Act (RSA, 1998a) was politically driven by the need to redress the inequities in society and to create equal opportunities for all citizens. However, this socialist-oriented political ideology of the new Government was not compatible with the capitalist principles on which the South African economy was based (Bond, 2005; Hart, 2006). Maintaining a strong economy through focus on market efficiency, competition and productivity was supported by the economic elite in South Africa as well as by the geopolitical agenda (Hart, 2008). Through conditional policy reforms attached to loans from the World Bank and IMF the new Government was persuaded to adopt a neo-liberal approach (Bond, 2005; Harvey, 2005). The neo-liberal doctrine suggests that human well-being can best be advanced by liberating individual entrepreneurial freedoms and skills in an institutional framework characterised by free markets and globalisation of trade (Harvey, 2005). It proposes limiting the control of the Government on the economy, as well as the privatisation of public services and property rights over natural resources (Harvey, 2005; Ahlers and Zwarteveen, 2009). Based on these neo-liberal principles the South African Government introduced the Growth, Employment and Redistribution (GEAR) policy in 1996, which focused on achieving equity by enlarging the 'wealth' cake. However, in a country characterised by structural inequalities along racial lines in terms of educational background and access to resources, emphasis on market competition between actors is unlikely to lead to equity. Moreover, shifting power from the state to the market and focusing on productivity seriously hampers the redistribution of natural resources to the previously-dispossessed groups in the society. According to Bond (2005), neo-liberal policies have amplified rather than corrected the economic distortions created during apartheid and it is argued that the neo-liberal doctrine has replaced racial segregation under apartheid with class segregation in contemporary South Africa (Bond, 2006; Harvey, 2005; Swatuk, 2008).

The dominance of the neo-liberal discourse becomes visible in the chosen approach for the implementation of the National Water Act and the priorities set for the water allocations (Bond, 2006). For example, the choice of a sectoral approach to water delivery might be suitable for the high-volume users in the better-served areas, but in the rural areas water resources are often used for multiple purposes and integrated service delivery would be more effective (Van Koppen and Jha, 2005). The smallholder farmers in the catchment indicated that they have to deal with different Government departments for their water supply depending on the purpose of the water use (e.g. domestic, various productive uses), while in practice the same water resources are being used. Increasing access to the water resource is therefore challenging, as it needs collaboration between the various Government departments. Moreover, it remains unclear in the Water Act under which category water use for small-scale commercial production falls (Perret, 2001). Water abstraction for subsistence farming is permitted under the Water Act without registration or payment (RSA, 1998a), while for all other water uses a licence needs to be granted. However, the smallholder farmers in the case-study catchment often only sell part of their 
harvest depending on the yields and market opportunities, which makes the water use for commercial purposes difficult to predict, and is, hence, licensed. Furthermore, to obtain a licence the Water Act stipulates that the water use should be in line with the catchment management strategy negotiated within the new water user platforms (RSA, 1998a). In the absence of organisational structures around water in the former homelands, meaningful representation in these new arenas will be problematic, which leaves the emerging individual smallholder farmers formally without rights to water for commercial uses and favours the established well-organised large-scale commercial farmers in the catchment. This is now acknowledged by the South African Government and the proposed granting of a general authorisation for small-scale commercial water use is currently debated. The water allocations at national level also clearly demonstrate the underlying neo-liberal discourse: even though the smallholder farmers in the case-study area indicated that a shortage of water limits their economic development, the Thukela River Basin is transferring approximately $75 \%$ of its surface water yield to adjacent river basins to support commercial activities of industries and hydro-power production in urban parts of the country (DWAF, 2003). Consultants hired by the Government to study the water availability and water use in the Thukela River Basin recommended continuation of water transfers to other parts of the country as, in their view, no strong economic drivers within the basin exist to stimulate development. They regard water resource development for the sole purpose of irrigation economically unviable and recommend allocating the water to other sectors (DWAF, 2003).

Even more striking is the lack of an integrated approach across sectors, which disconnects the water reform process from the land reform process. In South Africa the inequity in land and water resources is closely linked, with the smallholder farmers mainly relying on green water resources (Rockström et al., 1999; Savenije, 1999). Significant increases in access to water can therefore not be achieved in the overpopulated former homelands unless the inequity in land distribution is addressed simultaneously (Hope et al., 2004; 2008). Currently the distribution of land under the land reform program,e is based on the neo-liberal 'willing seller, willing buyer' principle, in which land is bought in conformity to market prices (DALA, 2006). However, this approach results in a slow pace of the land reform process (Lyne and Darroch, 2004; Lahiff and Cousins, 2005; Hart, 2006; Cousins, 2007; Peters, 2009) and, according to the smallholder farmers in the case-study catchment, only fragmented pieces of communal land become available with often limited access to (blue) water resources. For instance, through the land distribution programme the smallholder farmers have obtained approximately 600 ha of dry mountainous land adjacent to their community, and another piece of land that was offered to them was more than $10 \mathrm{~km}$ away from their current location. Moreover, it is slowly being acknowledged that, based on market prices, the Government will never be able to afford to buy sufficient land to radically address the existing inequity (DALA, 2006).

Finally, in the South African Constitution it is stated that the country should be run on a system of cooperative governance between the Government and the traditional governance structures (RSA, 1994). This principle is admirable from the reconciliation perspective; however, besides the additional challenges it creates in the former homelands, as described above, it is to a certain extent also a facade. With the Government having the constitutional authority, the democracy discourse is dominant and the role of the traditional authorities is limited to an advisory role, despite the protests of the traditional leaders
(Lehman, 2007). In this way the cooperative governance system reproduces the inherited inequalities between the Government and the traditional authorities. The dominant democratic discourse becomes further apparent in the manipulation of the traditional structure to comply with Government structures and the requirements for democratically-elected representation in the traditional governance structure (RSA, 2003), which has affected the executive power of the traditional authorities. Nonetheless, it can be debated as to who the traditional governance structure is representing, particularly after the manipulations by the apartheid regime (Mamdani, 1996). In the traditional governance structure the Black elite might be represented, but it can be questioned whether the rural poor are represented (Sjaastad and Cousins, 2008). It can therefore be argued that the adoption of a cooperative governance structure was a politically-motivated choice to support the Black elite rather than a prerequisite for the socio-economic development of the rural areas.

\section{Discussion and conclusions}

Although the National Water Act (RSA, 1998a) is comprehensive in its legislation and provides powerful legal tools to address poverty eradication and redress inequities inherited from the past, in reality little transition in the access to and control over water resources has been achieved (Bond, 2006; Cullis and Van Koppen, 2009; Merrey, 2008). This paper emphasises that water law on paper is not sufficient, as it is not implemented and enforced in a vacuum, but in a society thick with historicallyentrenched socio-economic and political inequities. The transition from apartheid to post-apartheid South Africa has been characterised by a negotiated transformation with emphasis on reconciliation. As a consequence the legacy of apartheid and the nature of the transitional arrangement still determine, to a large extent, today's political and economical reality, with the elite, White and some Black, in charge. Neo-liberal geopolitics has left the South African Government faced with the challenge to redress access to natural resources in an era characterised by the promotion of the private sector over the public sector (cf. Lahiff, 2003; cf. Hart, 2006; Swatuk, 2008). Hence, the Water Act is highly contested by the vested economic elite and up to now the status quo of an unfair distribution of water along racial lines is maintained, leaving the smallholder farmers in the study catchment managing in the margin.

The Water Act provides opportunities for citizens to contest unequal access to water resources through a bottom-up approach. However, smallholder farmers in the case-study catchment face various challenges that prevent them from claiming their rights. These can be summarised in 4 points. First, the institutional chaos created in the former homeland as a result of the formal plural governance structure directly influences the executive power and legitimacy of the various authorities, thwarts collaboration, and creates 'fuzziness'. Second, the tendency of authorities and NGOs to approach the smallholder farmers as a united community and offer services and resources on communal basis is problematic, as the farmers are divided and heterogeneous in their ambitions, which makes it difficult for individual farmers to advance their agricultural activities. Besides, it can be questioned if the residents in the former homeland should be approached as farmers, as a substantial part of the residents do not perceive themselves as such. This is in line with the statement of Dlali (2008: 44) 'most people currently living in the rural areas in South Africa are 'rural dwellers' rather than farmers'. Third, the disconnect between the water and land reform programs puts the smallholder farmers in the dilemma of acquiring 
land without (blue) water or water without land. Fourth, the low self-esteem as a result of the structural, racial and gender inequalities hinders the smallholder farmers from claiming their rights and challenging the unequal access to water for (productive) uses. The smallholder farmers adopt an underdog position and their attitude tends to be submissive, especially the female smallholder farmers. As argued by Zwarteveen et al. (2005), historically entrenched markers of behaviour that have served for generations to delineate and express the differentiation based on race and gender are not easily undone through legal changes.

The analytical framework used in this paper distinguishes 4 categories in which water law can be contested, based on Zwarteveen et al. (2005). The framework has been useful to comprehend the challenges met in the reform process, as it systematically analyses how water law is contested even if no explicit conflicts over or open claims on water exist. It reveals the different manifestations of struggles over access to water resources and how they are linked to self-perceived capacity of the actors to challenge or maintain the existing situation. In this way, the framework exposes how the implementation of the new water law is dynamically linked to deeper entrenched power structures in society and details how actors actively use and/or 'misuse' the water law to shape the negotiations over water. However, the framework focuses on water law, which only deals with water allocation and not with water distribution. Therefore, to increase the physical access of the smallholder farmers to (productive) water, distributional issues, such as the availability of hydraulic infrastructure and the capacity to manage, maintain and operate the infrastructure, need to be tackled simultaneously (Van der Zaag and Bolding, 2009). Investment in hydraulic infrastructure is closely linked to land availability and land tenure. Hence, this emphasises the importance of integrated and cross-sectoral approaches, as well as the importance of reviewing the cooperative governance structure in the former homelands. However, as argued before, water systems are not only shaped by, but also themselves shape and reinforce, social-political and economic relations, and historical analysis shows that hydraulic infrastructure has been used by wealthier farmers to assert their claims by ensuring that their 'rights' are fixed in permanent concrete structures (Mosse, 2008). Challenges associated with development of hydraulic infrastructure should therefore not withhold the Government from investing in hydraulic infrastructure in the previous disadvantaged former homelands.

In conclusion, the Water Act and other post-apartheid laws raised expectations amongst the various groups in society and gave hope for a more prosperous future, but after a decade of reconciliation the division of wealth is hardly unchanged (Swatuk, 2008). The ongoing protests and eruptions of violence in South Africa are resurgences of the underlying struggle over the structural inequities in society; the smallholder farmers in the casestudy area indicated that youth from their community had been involved in mid-2008 in xenophobic attacks (Mail \& Guardian, 2008), and they believe that the violence was an expression of the frustration about the dire conditions in which people live compared to the living conditions of the elite (cf. Hart, 2006; Swatuk, 2008; Peters, 2009). The difficulties encountered in the water reform process are illustrative of what is happening in the society at large. Although so far the elite have been able to maintain the status quo in the division of wealth, it can be questioned how robust the situation is, with the (potentially explosive) undercurrents in the society, and, hence, what price is being paid to maintain this status-quo?

\section{Acknowledgements}

The work presented in this paper was funded by DGIS and UNESCO-IHE. Implementation on-site was assisted by the School of Bioresources Engineering and Environmental Hydrology and the Centre for Environment, Agriculture and Development of the University of KwaZulu-Natal, South Africa. We thank the respondents for sharing their knowledge and opinions with us. Our gratitude goes to Ms. Hlengiwe Mabaso for translation during the interviews, to Mr. Michael Malinga for his assistance in the field and to Prof. Graham Jewitt for his valuable comments on earlier versions of this paper. The authors are grateful for the constructive comments made by the anonymous reviewers of Water $S A$.

\section{References}

AHLERS R and ZWARTEVEEN M (2009) The water question in feminism: water control and gender inequities in a neo-liberal era. Gender, Place Cult. 16 (4) 409-426.

BENTZON AW, HELLUM A, STEWART J, NCUBE W and AGERSNAP T (1998) Pursuing Grounded Theory in Law, South-North Experiences in Developing Women's Law. Mond Book, Harare.

BOELENS R, ZWARTEVEEN M and ROTH D (2005) Legal complexity in the analysis of water rights and water resources management. In: Roth D, Boelens R and Zwarteveen M (eds.) Liquid Relations: Contested Water Rights and Legal Complexity. Rutgers University Press, New Brunswick. 1-19.

BOND P (2005) Elite Transition: From Apartheid to Neoliberalism in South Africa. UKZN Press. URL: http://www.ukzn.ac.za/ccs (Accessed 21 March 2009).

BOND P (2006) Talk Left, Walk Right: South Africa's Frustrated Global Reforms. UKZN Press. URL: http://www.ukzn.ac.za/ccs (Accessed 21 March 2009).

CLEAVER F (1999) Paradoxes of participation: Questioning participatory approaches to development. J. Int. Dev. 11 597-612.

CONCA K (2006) Expert Networks: The Elusive Quest for Integrated Water Resources Management Governing Water: Contentions Transnational Politics and Global Institution Building. MIT Press, Cambridge.

CORNWALL A (2003) Whose voices? Whose choices? Reflections on gender and participatory development. World Dev. 31 (8) 1325-1342.

COUSINS B (2007) A Role For Common Property Institutions In Land Redistribution Programmes In South Africa. International Institute for Environment and Development, Gatekeeper Series No. 53.

CULLIS J and VAN KOPPEN B (2009) Applying the Gini coefficient to measure inequality of water use in the Olifants river water management area, South Africa. In: Swatuk LA and Wirkus L (eds.) Transboundary Water Governance in Southern Africa: Examining Unexplored Dimensions. Nomos, Baden-Baden. 91-110.

DE LANGE M (2004) Water policy and law review process in South Africa with a focus on the agricultural sector. In: Mollinga PP and Bolding A (eds.) The Politics of Irrigation Reform: Contested Policy Formulation and Implementation in Asia, Africa, and Latin America. Ashgate, London. 11-56.

DLALI DM (2008) Food security in a developmental state. New Agenda, S. Afr. J. Soc. Econ. Polic. (4 ${ }^{\text {th }}$ quarter 2008) 43-45.

DALA (DEPARTMENT OF AGRICULTURE AND LAND AFFAIRS, SOUTH AFRICA) (2006) Land and Agrarian reform in South Africa: 1994-2006. Paper presented at the International Conference on Agrarian Reform and Rural Development, Porto Alegre, Brazil, 7 to 10 March 2006.

DWAF (DEPARTMENT OF WATER AFFAIRS AND FORESTRY, SOUTH AFRICA) (2003) Thukela Water Management Area: overview of water availability and utilization. DWAF Report No. (07/000/00/0203). Department of Water Affairs and Forestry, Pretoria.

HART G (2006) Denaturalizing dispossession: Critical ethnography in the age of resurgent imperialism. Antipode 38 (5) 977-1004. 
HART G (2008) The provocation of neoliberalism: Contesting the nation and liberation after apartheid. Antipode 40 (4) 678-705.

HARVEY D (2005) A Brief History of Neoliberalism. Oxford University Press, London.

HOPE RA, JEWITT GPW and GOWING JW (2004) Linking the hydrological cycle and rural livelihoods: a case study in the Luvuvhu catchment, South Africa. Phys. Chem. Earth 29 1209-1217.

HOPE RA, GOWING JW and JEWITT GPW (2008) The contested future of irrigation in African rural livelihoods: analysis from a water scarce catchment in South Africa. Water Polic. 10 173-192.

LAHIFF E (2003) The politics of land reform in southern Africa. IDS Sustainable Livelihoods in Southern Africa Research Paper 19. Institute of Development Studies, Brighton.

LAHIFF E and COUSINS B (2005) Smallholder agriculture and land reform in South Africa. IDS Bull. 36 (2) 127-131.

LEHMAN HP (2007) Deepening democracy? Demarcation, traditional authorities and municipal elections in South Africa. Soc. Sci. J. 44 301-317.

LYNE MC and DARROCH MAG (2004) Land redistribution in KwaZulu-Natal, South Africa: five census surveys of farmland transactions, 1997-2001. BASIS CRSP Management Entity. URL: http:// www.basis.wisc.edu (Accessed 28 May 2009).

MAIL \& GUARDIAN (2008) Special Report on Xenophobia in South Africa. URL: http://www.mg.co.za/specialreport/xenophobia (Accessed 20 May 2008).

MAIR LP (1969) African marriage and social change. In: Phillips A (ed.) Survey of African Marriage and Family Life ( $2^{\text {nd }}$ edn.) Oxford University Press, London.

MAMDANI M (1996) Citizens and Subject: Contemporary Africa and the Legacy of Late Colonialism. Princeton University Press, New Jersey.

MCCUSKER B and RAMUDZULI M (2007) Apartheid spatial engineering and land use change in Mankweng, South Africa: 1963-2001. Geogr. J. 173 (1) 56-74.

MEINZEN-DICK R and PRADHAN R (2005) Analyzing water rights, multiple uses and intersectoral water transfers. In: Roth D, Boelens $\mathrm{R}$ and Zwarteveen M (eds.) Liquid Relations: Contested Water Rights and Legal Complexity. Rutgers University Press, New Brunswick. 237-253.

MERREY DJ (2008) When good intentions are not enough: is water reform a realistic entry point to achieve social and economic equity? Proc. $9^{\text {th }}$ WaterNet/WARFSA/GWP-SA Symposium, Johannesburg, 29-31 October 2008.

MOLLE F (2008) Nirvana concepts, narratices and policy models: Insights from the water sector. Water Alternatives 1 (1) 131-156.

MOLLINGA PP (2008) Water Policy - Water Politics: Social Engineering and Strategic Action in Water Sector Reform. In: Scheumann W, Neubert S and Kipping M (eds.) Water Politics and Development Cooperation. Springer-Verlag, Berlin.

MOSSE D (2008) Epilogue: the cultural politics of water: a comparative perspective. J. S. Afr. Stud. 34 (4) 937-946.

OMER-COOPER JD (1994) History of Southern Africa (2 ${ }^{\text {nd }}$ edn.) James Currey Ltd, Oxford.

PENZHORN C (2005) Participatory research: opportunities and challenges for research with women in South Africa. Women's Stud. Int. Forum 28 343-354.

PERRET SR (2001) New water policy, irrigation management transfer and smallholding irrigation schemes in South Africa: institutional challenges. FAO, Rome. URL: www.fao.org/landandwater (Accessed 16 August 2009).

PETERS PE (2009) Challenges in land tenure and land reform in Africa: anthropological contributions. World Dev. 37 (8) 1317-1325.

PICKLES J and WEINER D (1991) Rural and regional restructuring of apartheid: ideology, development policy and the competition for space. Antipode 23 (1) 2-32.

ROCKSTRÖM J, GORDON L, FOLKE C, FALKENMARK M and ENGWALL M (1999) Linkages among water vapour flows, food production, and terrestrial ecosystem services. Cons. Ecol. 3 (2) 5.
ROSS R (1999) A Concise History of South Africa. Cambridge University Press, Cambridge.

RSA (REPUBLIC OF SOUTH AFRICA) (1996) Constitution of the Republic of South Africa. URL:www.info.gov.za/documents/constitution (Accessed 18 July 2008).

RSA (REPUBLIC OF SOUTH AFRICA) (1998a) National Water Act. Gov. Gaz. 398, No. 19182. Cape Town.

RSA (REPUBLIC OF SOUTH AFRICA) (1998b) Local Government: Municipal Structures Act. Gov. Gaz. 402, No. 19614.

RSA (REPUBLIC OF SOUTH AFRICA) (2003) Traditional Leadership and Governance Framework Amendment Act. Gov. Gaz. 462, No 25855.

RSA (REPUBLIC OF SOUTH AFRICA) (2004) Black Economic Empowerment Act. Gov. Gaz. 463, No. 25899.

SASSA (SOUTH AFRICAN SOCIAL SECURITY AGENCY) (2008) You and your grants 2009/10. SASSA. URL: www.sassa.gov.za (Accessed 24 August 2009).

SAVENIJE HHG (1999) The role of green water in food production in Sub-Saharan Africa. FAO, Rome. URL: www.fao.org/landandwater (Accessed 21 July 2009).

SIMPUNGWE E (2006) Water, stakeholders and common ground: challenges for multi-stakeholder platforms in water resource management in South Africa. Ph.D. Dissertation, Wageningen University.

SJAASTAD E and COUSINS B (2008) Formalisation of land rights in the South: an overview. Land Use Polic. 26 1-9.

STEYL I, VERSFELD DB and NELSON PJ (2000) Strategic environmental assessment for water use: Mhlathuze Catchment, KwaZuluNatal. Department of Water Affairs and Forestry, Pretoria, South Africa.

SPIERTZ HLJ (2000) Water rights and legal pluralism: some basics of a legal anthropological approach. In: Bruns BR and MeinzenDick RS (eds.) Negotiating Water Rights. Intermediate Technology Publications, London.

SWATUK LA (2008) A political economy of water in Southern Africa. Water Alternatives 1 (1) 24-47.

VAN DER ZAAG P and RÖLING N (1996) The water acts in the Nyachowa catchment area. In: Manzungu E and van der Zaag P (eds.) The Practice of Smallholder Irrigation: Case Studies from Zimbabwe. University of Zimbabwe Publications, Harare. 161-190.

VAN DER ZAAG P and BOLDING A (2009) Water governance in the Pungwe River Basin: Institutional limits to the upscaling of hydraulic infrastructure. In: Swatuk LA and Wirkus L (eds.) Transboundary Water Governance in Southern Africa: Examining Unexplored Dimensions. Nomos, Baden-Baden. 163-177.

VAN KOPPEN B and JHA N (2005) Redressing racial inequities through water law in South Africa, interactions and contest among legal frameworks. In: Roth D, Boelens R and Zwarteveen M (eds.) Liquid Relations: Contested Water Rights and Legal Complexity. Rutgers University Press, New Brunswick. 195-214.

VON BENDA-BECKMANN F (1997) Citizens, strangers and indigenous peoples: conceptual politics and legal pluralism. In: Von Benda-Beckmann F, Von Benda-Beckmann K and Hoekema A (eds.) Natural resources, Environment and Legal Pluralism. Yearbook Law and Anthropology 9 1-42. Martinus Nijhoff, Leiden.

VON BENDA-BECKMANN F (2002) Who is afraid of legal pluralism? J. Leg. Pluralism 27 1-46.

WILSON D (1999) Exploring the limits of public participation in local government. Parliamentary Aff. 52 (2) 246-259.

WILSON M and THOMPSON L (eds.) (1969) The Oxford History of South Africa Volume 1. Clarendon Press, London.

ZWARTEVEEN M, ROTH D and BOELENS R (2005) Water rights and legal pluralism: beyond analysis and recognition. In: Roth D, Boelens B and Zwarteveen M (eds.) Liquid Relations: Contested Water Rights and Legal Complexity. Rutgers University Press, New Brunswick. 254-268. 